See discussions, stats, and author profiles for this publication at: https://www.researchgate.net/publication/304331066

\title{
Highly Similar Morphologies Between Chromosomes Bearing U2 snRNA Gene Clusters in the Group Astyanax Baird and Girard, 1854 (Characiformes, Characidae): An Evolutionary Approach in...
}

Article in Zebrafish · June 2016

DOI: 10.1089/zeb.2016.1292

CITATIONS

6

3 authors:

Diovani Piscor

Universidade Estadual de Mato Grosso do Sul

16 PUBLICATIONS 60 CITATIONS

SEE PROFILE

Patricia Pasquali Parise-Maltempi

São Paulo State University

45 PUBLICATIONS 339 CITATIONS

SEE PROFILE
READS

60

Liano Centofante

Universidade Federal de Mato Grosso (UFMT)

37 PUBLICATIONS 409 CITATIONS

SEE PROFILE

Some of the authors of this publication are also working on these related projects:

PACU-PEVAS FISH (CHARACIDAE, MYLEINAE) OF PANTANAL MATOGROSSENSE: CHARACTERIZATION GENETIC, PHYSICAL- CHEMICAL AND POTENTIAL SPECIES TO PISCICULTURE. View project

Diversidade Genética dos Ancistrini de Mato Grosso View project 


\title{
Highly Similar Morphologies Between Chromosomes Bearing U2 snRNA Gene Clusters in the Group Astyanax Baird and Girard, 1854 (Characiformes, Characidae): An Evolutionary Approach in Species with $2 \mathrm{n}=36,46,48$, and 50
}

\author{
Diovani Piscor, ${ }^{1}$ Liano Centofante, ${ }^{2}$ and Patricia Pasquali Parise-Maltempi ${ }^{1}$
}

\begin{abstract}
Repetitive sequences and their chromosomal locations have been widely studied in species of the Astyanax genus. However, the chromosomal organization of U2 snDNA remains largely unknown. The aims of this study were to examine the chromosomal contexts of U2 snRNA and 5S rRNA genes in Astyanax species and determine the degree of chromosome morphological similarity between species with different diploid numbers. Clusters of U2 snDNA and 5S rDNA were determined in nine species of Astyanax, including two karyomorphs of Astyanax fasciatus Cuvier, 1819. All species exhibited U2 snDNA clusters on two chromosome pairs, except Astyanax mexicanus De Filippi, 1853 (one pair). The 5S rDNA clusters were located on one chromosome pair in Astyanax altiparanae Garutti and Britski, 2000, and Astyanax marionae Eigenmann, 1911, two pairs in Astyanax abramis Jenyns, 1842, Astyanax asuncionensis Géry, 1972, Astyanax bockmanni Vari and Castro, 2007, Astyanax eigenmanniorum Cope, 1894, A. fasciatus (karyomorphs I and II), and Astyanax schubarti Britski, 1964, and four pairs in A. mexicanus. The relationships between the repetitive sequences in different species suggest that $A$. schubarti and $A$. mexicanus exhibit an unusual U2 snDNA chromosomal format as a result of events occurring in the evolutionary history of the Astyanax group.
\end{abstract}

\section{Introduction}

$\mathbf{T}$ He Astranax Genus contains numerous species (about 140 species), ${ }^{1}$ many of which have not been examined cytogenetically. Diploid number ranges from $2 n=36$ chromosomes (e.g., A. schubarti) ${ }^{2}$ to $2 n=50$ chromosomes (most species) as in A. altiparanae ${ }^{3}$ and $A$. bockmanni. ${ }^{4}$ Intermediate diploid numbers are also observed in species such as $A$. fasciatus $(2 n=46)^{5}$ and Astyanax scabripinnis Jenyns, 1842 $(2 n=48) .{ }^{6}$ However, the latter two species are considered to be species complexes that present variable diploid numbers (karyomorphs). For example, different karyomorphs of $A$. fasciatus were found under sympatric conditions. ${ }^{7}$ Astyanax is therefore a promising model for studies of karyotype evolution.

The chromosomal locations of many repetitive sequences are well characterized in Astyanax, nevertheless some repetitives show variations related to cluster numbers, as the locations of $18 \mathrm{~S}$ ribosomal DNA (18S rDNA). For instance,
Fernandes and Martins-Santos ${ }^{8}$ described four and seven sites of $18 \mathrm{~S}$ rDNA in different A. altiparanae populations from the Paraná River Basin (Paraná state-PR, Brazil), whereas Peres et al. ${ }^{9}$ described only a single $18 \mathrm{~S}$ rDNA site in a population of $A$. altiparanae from the upper Paraná River Basin (São Paulo state-SP, Brazil). Conversely, fluorescent labeling showed that $5 \mathrm{~S}$ rDNA location was conserved to the same chromosome pair in these A. altiparanae populations.

The chromosomal locations of histone and U small nuclear RNA (U snRNA) sequences are conserved. ${ }^{10-13}$ More recently, Piscor and Parise-Maltempi ${ }^{14}$ studied eight species of Astyanax and demonstrated that the chromosomal locations of $\mathrm{H} 3$ histone gene clusters were highly conserved in A. abramis, A. asuncionensis, A. altiparanae, A. bockmanni, A. eigenmanniorum, and $A$. fasciatus. Silva et al. ${ }^{13}$ observed that the U1 and U2 snDNA clusters were located at different chromosomal sites in different Astyanax species but exhibited strong conservation in the number of sites per genome.

\footnotetext{
${ }^{1}$ Laboratório de Citogenética, Departamento de Biologia, Instituto de Biociências, Universidade Estadual Paulista "Júlio de Mesquita Filho" (UNESP), Rio Claro, Brazil.

${ }^{2}$ Laboratório de Genética Animal, Departamento de Biologia e Zoologia, Instituto de Biociências, Universidade Federal de Mato Grosso (UFMT), Cuiabá, Brazil.
} 
Considering Astyanax a group with wide distribution and distinct cytogenetic features, the aims of this article were to compare the chromosomal organization of $\mathrm{U} 2 \mathrm{snDNA}$ and $5 \mathrm{~S}$ rDNA in nine species, including those with different diploid numbers, and determine parameters underlying the chromosome evolution of U2 snRNA genes in the Astyanax genus.

\section{Materials and Methods}

\section{Sampling and classical cytogenetics}

Astyanax specimens were obtained from locations in Brazil as follows: three A. abramis and four A. asuncionensis specimens from the Bento Gomes River in Mato Grosso state (MT), six A. marionae specimens from the Rio Claro stream in Mato Grosso state (MT), five A. altiparanae specimens and one $A$. schubarti specimen from the Piracicaba River in São Paulo state (SP), three A. bockmanni specimens from the Iguatemi River in Mato Grosso do Sul state (MS), two A. aff. fasciatus specimens (karyomorph I) from the Corumbataí River tributary (SP), five A. fasciatus specimens (karyomorph II) from the Ribeirão Claro River (SP), and three A. mexicanus and three A. eigenmanniorum specimens from aquariophiles in Brazil. Chromosomes were obtained as described by Foresti et al., ${ }^{15}$ and chromosome morphologies were determined according to the arm ratios (the most frequently used classification system for fish chromosomes in Brazil), as cited by Piscor et al. ${ }^{16}$

\section{Isolation of repetitive DNA probes and fluorescence in situ hybridization}

Genomic DNA was extracted from fin samples as described by Sambrook and Russell. ${ }^{17}$ The $5 \mathrm{~S}$ rDNA probe was prepared using polymerase chain reaction (PCR) with primers described by Pendás et al. ${ }^{18}$ and Martins and Galetti ${ }^{19}$ (A, $5^{\prime}$-TAC GCC CGA TCT CGT CCG ATC-3'; and B, 5'-CAG GCT GGT ATG GCC GTA AGC-3'). The U2 snDNA probe was prepared using PCR with primers described by Bueno et al. ${ }^{20}$ (U2F, $5^{\prime}$ ATC GCT TCT CGG CCT TAT G-3'; and U2R, $5^{\prime}$-TCC CGG CGG TAC TGC AAT A-3'). The 5S rDNA probe was labeled by PCR with biotin-14-dATP (Invitrogen, San Diego, CA), and the U2 snDNA probe was labeled by PCR with digoxigenin11-dUTP (Roche, Mannheim, Germany). Probes labeled with digoxigenin-11-dUTP were detected using antidigoxigeninrhodamine (Roche), and probes labeled with biotin-14-dATP were detected using Alexa Fluor 488-conjugated streptavidin (Invitrogen). Single- and two-color fluorescence in situ hybridization (FISH) was performed using mitotic metaphasic chromosomes, according to Pinkel et al. ${ }^{21}$ and with modifications as described by Cabral-de-Mello et al. ${ }^{22}$ Chromosomes were counterstained with VECTASHIELD Mounting Medium (Vector, Burlingame, CA) containing DAPI (4',6-diamidino-2phenylindole). Chromosomes and fluorescent signals were visualized with an Olympus BX51 microscope coupled to a digital camera (Olympus model D71). Images were captured using DP Controller software.

\section{Results}

Species with $2 n=50$ chromosomes were A. abramis, A. asuncionensis, A. altiparanae, A. bockmanni, A. eigenmanniorum, A. mexicanus (Figs. $1 \mathrm{~A}-\mathrm{F}$ and Table 1 ), and $A$. aff. fasciatus (karyomorph I; the first described karyomorph for this population) (Fig. 2A and Table 1). All the examined A. mexicanus cells contained one acrocentric B chromosome (Fig. 1F, box). Species with smaller diploid numbers were $A$. marionae $(2 n=48$ chromosomes), A. fasciatus (karyomorph II; $2 n=46)$, and $A$. schubarti $(2 n=36)$ (Figs. $2 \mathrm{~B}-\mathrm{D}$, respectively; Table 1).

The U2 snDNA clusters were observed on two chromosome pairs in eight of the nine Astyanax species (including the two A. fasciatus karyomorphs) (Figs. 1 and 2; Table 1). In A. mexicanus, U2 snDNA was observed on only one chromosome pair (Fig. 1F and Table 1). The U2 snDNA clusters were located on chromosome pairs 17 and 20 (sm) in A. abramis (Fig. 1A), pairs 11 and 13 (sm) in A. asuncionensis (Fig. 1B), pairs 10 and $13(\mathrm{sm})$ in A. altiparanae (Fig. 1C), pairs 5 and 11 (sm) in A. bockmanni (Fig. 1D), pairs 15 (sm) and 16 (st) in $A$. eigenmanniorum (Fig. 1E), pair $8(\mathrm{sm})$ in $A$. mexicanus (Fig. 1F), pairs $13(\mathrm{sm})$ and 15 (st) in A. aff. fasciatus (karyomorph I) (Fig. 2A), pairs 5 and 9 (sm) in A. marionae (Fig. 2B), pairs 7 and 10 (sm) in A. fasciatus (karyomorph II) (Fig. 2C), and pairs 7 and 14 (sm) in A. schubarti (Fig. 2D). All fluorescent signals were located in the pericentromeric regions, with the exception of an interstitial signal observed on pair 7 in A. schubarti (Fig. 2D).

In five of the seven species with $2 n=50$ chromosomes (A. abramis, A. asuncionensis, A. bockmanni, A. eigenmanniorum, and A. mexicanus), the 5S rDNA was located on pair $2(\mathrm{~m})$ (Figs. 1A, B, D-F, respectively). In A. altiparanae, the 5S rDNA was located on pair 5 (sm) (Fig. 1C), and in A. aff. fasciatus (karyomorph I), the 5S rDNA was observed on pairs $3(\mathrm{~m})$ and 21 (a) (Fig. 2A). Species with 5S rDNA on pair 2 (m) also exhibited signals in pericentromeric regions on other chromosomes. Pericentromeric fluorescent signals were noted on pair 23 (st) in A. abramis (Fig. 1A), pair 25 (a) in A. asuncionensis (Fig. 1B), pair 19 (a) in A. bockmanni (Fig. 1D), pair 22 (a) in A. eigenmanniorum (Fig. 1E), and pairs 15 (sm), 22 (a), and 25 (a) in A. mexicanus (Fig. 1F). The three species with smaller diploid numbers, $A$. marionae $(2 n=48)$, A. fasciatus karyomorph II $(2 n=46)$, and $A$. schubarti $(2 n=36)$, harbored 5S rDNA clusters at pericentromeric regions on pair 22 (a) (A. marionae; Fig. 2B), pairs 3 (m) and 22 (a) (A. fasciatus karyomorph II; Fig. 2C), and pairs 3 and 4 (m) (A. schubarti; Fig. 2D).

A summary diagram indicating the chromosomal locations of the U2 snDNA clusters in the nine Astyanax species is shown in Figure 3. Note that three groups were formed: the first group with two chromosome pairs bearing U2 snDNA clusters shared by several species (Fig. 3A), the second group with only one pair (Fig. 3B), and the third group with two pairs but the first pair with interstitial clusters (Fig. 3C).

\section{Discussion}

As demonstrated by previous cytogenetic observations, the most common diploid number in the Astyanax genus is $2 n=50$ chromosomes. This is consistent with the majority of species in the family Characidae. ${ }^{2}$ However, other diploid chromosome numbers are observed in the Astyanax genus, such as the species with $2 n=36,46$, and 48 examined in this study. Furthermore, species complexes with variable diploid numbers are found in Astyanax, such as the "scabripinnis complex" and the "fasciatus complex" (see, e.g., ${ }^{23,24}$ ). Here, A. fasciatus karyomorphs from the same river system were examined that had two different diploid numbers $(2 n=46$ and 50). Astyanax 

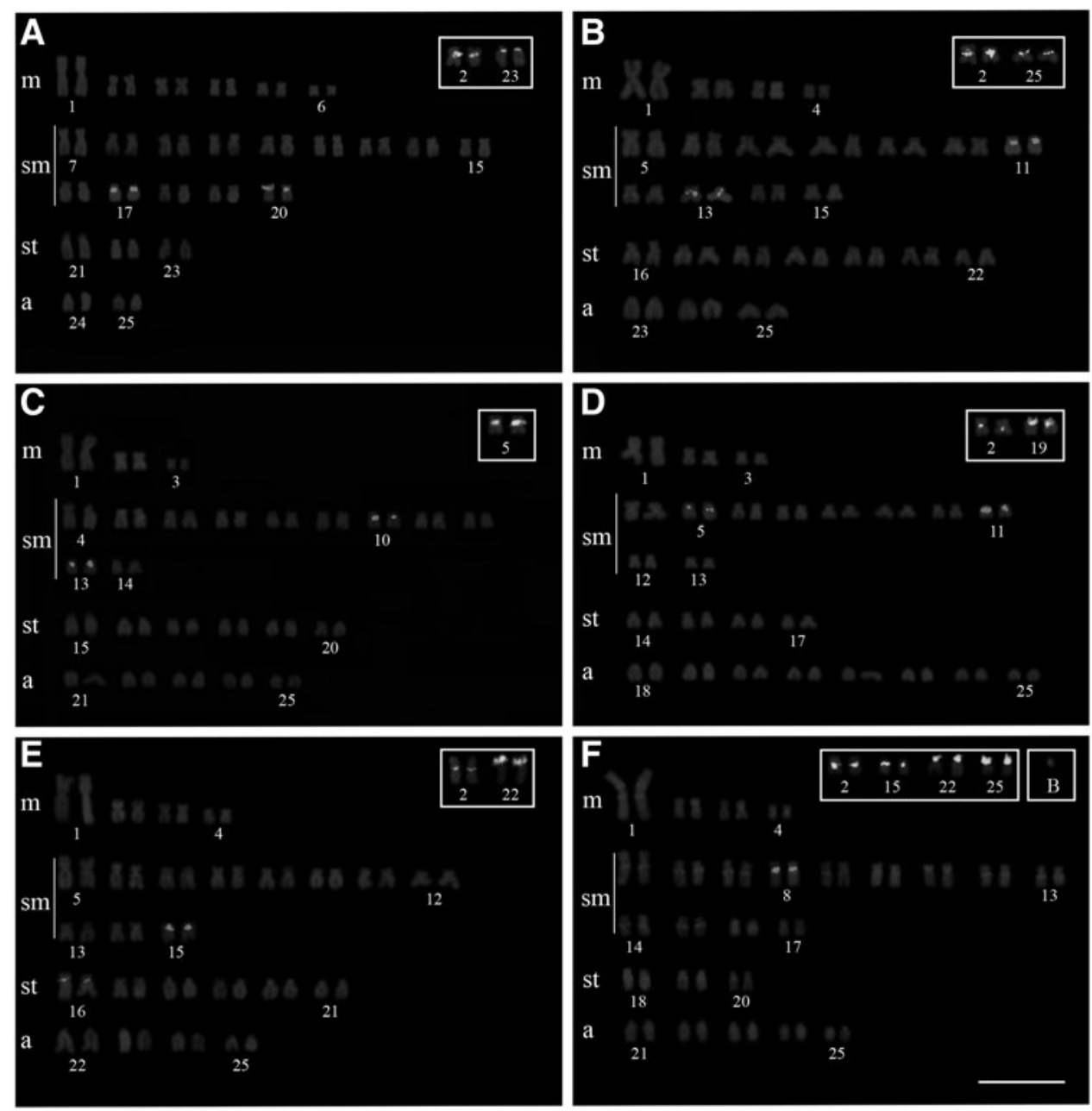

FIG. 1. Locations of U2 snDNA and $5 \mathrm{~S}$ rDNA clusters on chromosomes of Astyanax species with $2 \mathrm{n}=50$ chromosomes. (A) Astyanax abramis, (B) Astyanax asuncionensis, (C) Astyanax altiparanae, (D) Astyanax bockmanni, (E) Astyanax eigenmanniorum, and (F) Astyanax mexicanus. Karyotypes indicate the chromosome pairs with U2 snDNA clusters, and boxes indicate pairs with $5 \mathrm{~S}$ rDNA clusters. Scale bar $=10 \mu \mathrm{m}$.

Table 1. Chromosomal Data in Species of Astyanax with U2 snDNA Clusters

\begin{tabular}{|c|c|c|c|c|c|c|}
\hline Species & $2 n$ & Karyotype formulae & $F N^{\mathrm{a}}$ & $5 S^{\mathrm{b}}$ & $U 2^{\mathrm{c}}$ & References \\
\hline Astyanax abramis & 50 & & 96 & 4 & 4 & Present study \\
\hline Astyanax asuncionensis & 50 & $\begin{array}{l}12 m+28 s m+6 s t+4 a \\
8 m+22 s m+14 s t+6 a\end{array}$ & 94 & 4 & 4 & Present study \\
\hline Astyanax altiparanae & 50 & $6 m+22 s m+12 s t+10 a$ & 90 & 2 & 4 & Present study \\
\hline A. altiparanae & 50 & $10 m+16 s m+16 s t+8 a$ & - & 2 & 4 & Silva et al. ${ }^{13}$ \\
\hline Astyanax bockmanni & 50 & $6 m+20 s m+8 s t+16 a$ & 84 & 4 & 4 & Present study \\
\hline A. bockmanni & 50 & $8 m+14 s m+12 s t+16 a$ & - & 4 & 4 & Silva et al. ${ }^{13}$ \\
\hline Astyanax eigenmanniorum & 50 & $8 m+22 s m+12 s t+8 a$ & 92 & 4 & 4 & Present study \\
\hline Astyanax aff. fasciatus (karyotype I) & 50 & $8 m+20 s m+12 s t+10 a$ & 90 & 4 & 4 & Present study \\
\hline A. fasciatus (karyotype II) & 46 & $8 m+18 s m+16 s t+4 a$ & 88 & 4 & 4 & Present study \\
\hline A. fasciatus & 46 & $10 m+14 s m+14 s t+8 a$ & - & 4 & 4 & Silva et al. ${ }^{13}$ \\
\hline Astyanax jordani & $50+\mathrm{B}^{\mathrm{d}}$ & $8 m+18 s m+12 s t+12 a$ & - & 10 & 2 & Silva et al. ${ }^{13}$ \\
\hline Astyanax marionae & 48 & $8 m+24 s m+10 s t+6 a$ & 90 & 2 & 4 & Present study \\
\hline Astyanax mexicanus & $50+B^{d}$ & $8 m+26 s m+6 s t+10 a$ & 90 & 8 & 2 & Present study \\
\hline Astyanax paranae Eigenmann, 1914 & $50+\mathrm{B}^{\mathrm{d}}$ & $8 m+22 s m+10 s t+10 a$ & - & 4 & 4 & Silva et al. ${ }^{13}$ \\
\hline Astyanax schubarti & 36 & $12 m+16 s m+4 s t+4 a$ & 68 & 4 & 4 & Present study \\
\hline
\end{tabular}

${ }^{\mathrm{a}}$ Fundamental numbers.

${ }^{\mathrm{b}}$ Numbers of clusters (5S rDNA).

${ }^{\mathrm{c}}$ Numbers of clusters (U2 snDNA).

${ }^{\mathrm{d}} \mathrm{B}$ chromosomes.

FN, fundamental number. 
FIG. 2. Locations of U2 snDNA and 5S rDNA clusters on chromosomes of Astyanax marionae $(2 \mathrm{n}=48)$, Astyanax schubarti $(2 \mathrm{n}=36)$, and two Astyanax fasciatus populations (karyomorph I, 2n=50, and karyomorph II, $2 \mathrm{n}=46$ ). (A) Astyanax aff. fasciatus (karyomorph I), (B) A. marionae, (C) A. fasciatus (karyomorph II), and (D) A. schubarti. Karyotypes indicate the chromosome pairs with U2 snDNA clusters, and boxes indicate pairs with $5 \mathrm{~S}$ rDNA clusters. Scale bar $=10 \mu \mathrm{m}$.
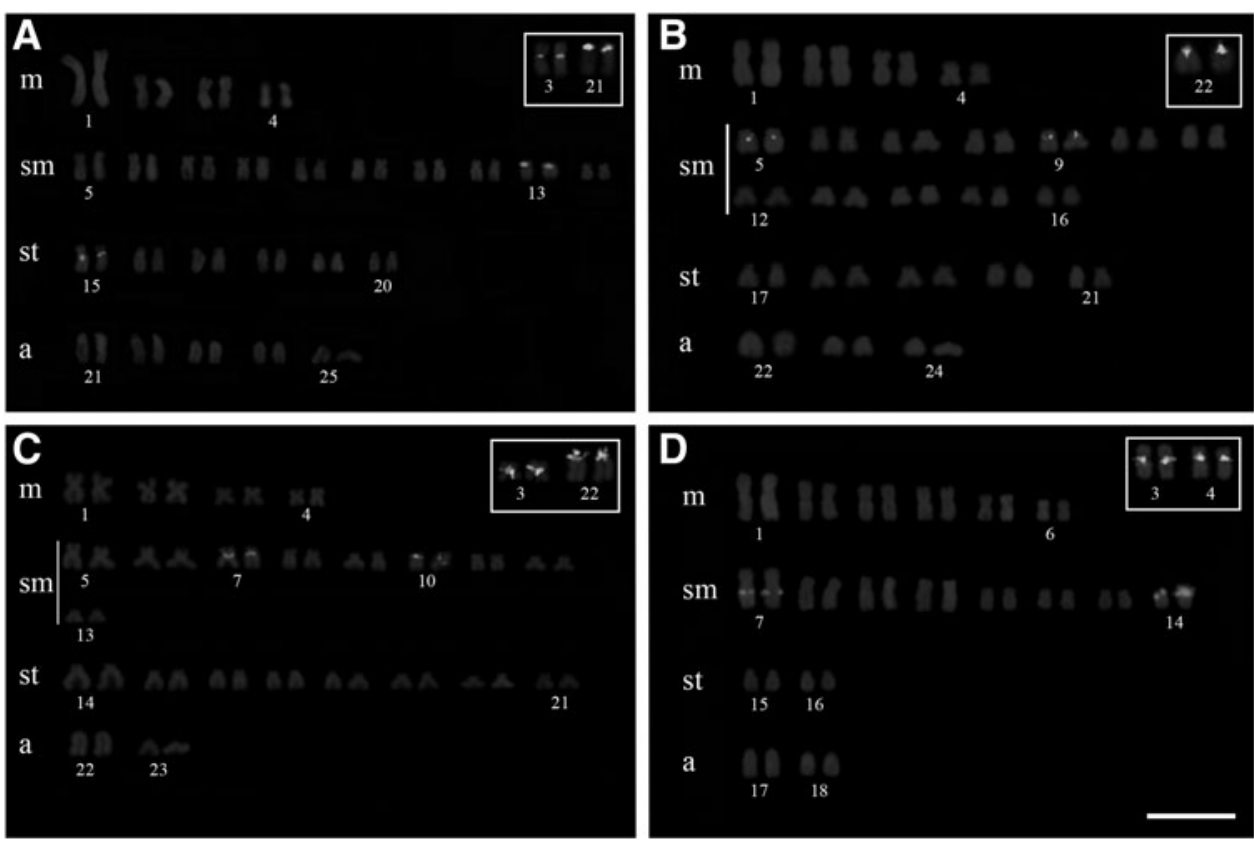

fasciatus is known to have several karyomorphs, mostly with $2 n=46,48$, and 50 chromosomes. $^{7}$

The Astyanax genus is distinguished cytogenetically by diploid number variability from $2 n=36$ chromosomes for A. schubarti ${ }^{2}$ and Astyanax correntinus Holmberg, 1891, ${ }^{25}$ to $2 n=50$ chromosomes for most species, for example, A. altiparanae and A. bockmanni.$^{3,4}$ Variations in karyotype formula and fundamental number $(\mathrm{FN})$ are also widely observed even in populations of the same species. For example, Fernandes and Martins-Santos ${ }^{3}$ reported two different karyotype formulae and $\mathrm{FN}$ in two A. altiparanae populations from the Indios and Paraná rivers (PR, Brazil), and these values differ from those of the Piracicaba River (SP, Brazil) studied here. In contrast, FISH examination has identified that repetitive sequences showed similar chromosomal locations in Astyanax species.

Chromosomal locations of 5S rDNA are conserved in some Astyanax and exhibit three forms. ${ }^{26}$ The form found in most species, including the A. fasciatus karyomorphs ana- lyzed here, exhibits one metacentric pair and one acrocentric or subtelocentric pair with 5S rDNA sites located on the long arm, both near the centromere. ${ }^{26}$ According to Vicari et al. ${ }^{27}$ Astyanax species with two chromosome pairs bearing $5 \mathrm{~S}$ rDNA sites exhibit probable synapomorphic features.

In fish, 5S rDNA and other repetitive DNA clusters may be located on the same chromosome pair. For example, while 5S rRNA and histone genes can occur on the same chromosome in Astyanax species, ${ }^{10,14}$ the $5 \mathrm{~S}$ rDNA is close to $18 \mathrm{~S}$ rDNA clusters in Bryconamericus aff. iheringii Boulenger, 1887, ${ }^{16}$ another characid fish. The chromosomal locations of the $5 \mathrm{~S}$ rDNA and U2 snDNA clusters were not consistently linked in the Astyanax species examined here because that these represent two distinct classes of repetitive DNA with completely different functions. Supiwong et al. ${ }^{28}$ found that U2 snDNA and $5 \mathrm{~S}$ rDNA sequences were also carried on different chromosome pairs in the naked catfish Mystus bocourti Bleeker, 1864 (Siluriformes). This spatial separation of 5S rDNA and U2 snDNA appears to be a common feature in fish (see, e.g., ${ }^{29,30}$ ).
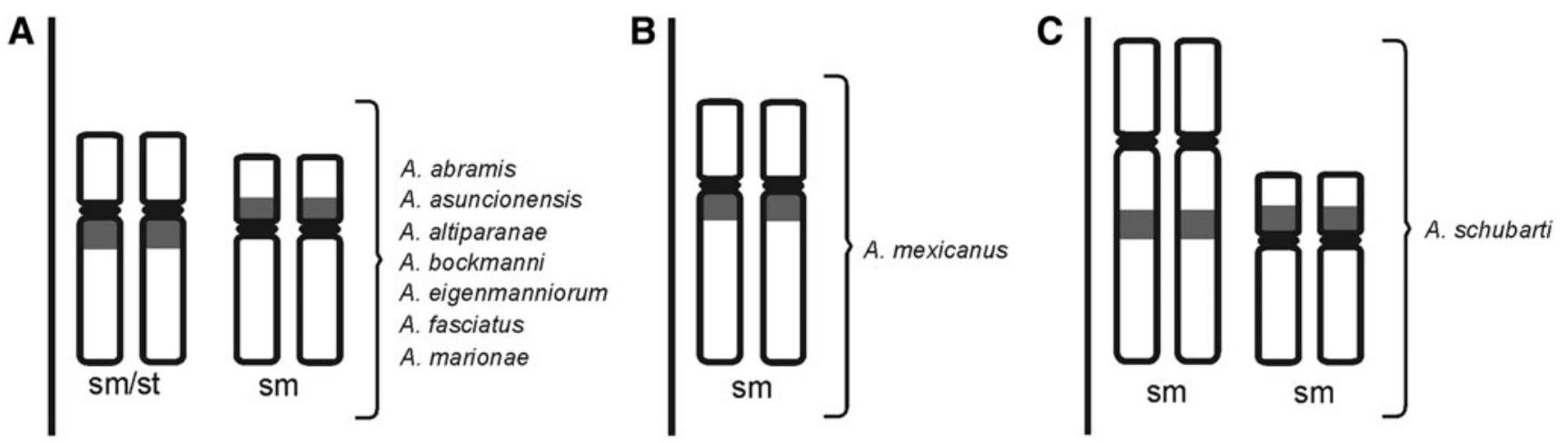

FIG. 3. Diagram indicating the chromosome pairs bearing U2 snDNA clusters in the nine Astyanax species. (A) Species with very similar chromosome pairs (pericentromeric regions), (B) A. mexicanus, with only one chromosome pair carrying U2 snDNA (pericentromeric region), and (C) A. schubarti, with two chromosome pairs carrying U2 snDNA (pair 7, interstitial location, and pair 14, pericentromeric location). U2 snDNA clusters are shown in gray. 
All the species examined here had clusters of U2 snDNA on two chromosome pairs, with the exception of $A$. mexicanus (one pair; Fig. 3). Therefore, our results suggest that the two pairs with U2 snDNA clusters may represent a similar form shared by species of the first group (Fig. 3A), and the only one chromosome pair of A. mexicanus (Fig. 3B) and two pairs of A. schubarti (Fig. 3C) represent different forms of genomic organization of U2 snRNA genes. These two different forms may be explained due to probable reduction in the diploid number $(2 n=36)$ of $A$. schubarti and ancient separation of $A$. mexicanus from the South America as previously proposed by Piscor and Parise-Maltempi. ${ }^{14}$

Recently, Silva et al. ${ }^{13}$ found U2 snDNA clusters on two chromosome pairs in different Astyanax species, except in Astyanax jordani Hubbs and Innes, 1936 (one pair). Silva et al. ${ }^{13}$ also showed that, while U1 and U2 snRNA genes were located on different chromosome pairs in different species, the numbers of U1 and U2 sites per genome were strongly conserved. Martins and Galetti ${ }^{19}$ proposed that $5 \mathrm{~S}$ rDNA on a single pair of chromosomes probably represented a more ancient genomic condition in Leporinus Spix, 1829 (Anostomidae).

The eyed epigean form (surface fish) of A. mexicanus is widely distributed in northeastern Mexico and southern Texas, and the eyeless hypogean forms (cavefish) live in some caves inside this extension. ${ }^{31}$ Therefore, an ancestral link is possible between the single pair of chromosomes carrying U2 snDNA in A. mexicanus from Mexico and single U2 snDNA pair in other species of Astyanax from North and Central America, as for example, A. jordani studied by Silva et al. ${ }^{13}$ that also showed one chromosome pair bearing U2 snDNA clusters.

In summary, the variability in diploid chromosome number in the Astyanax genus is not reflected in the chromosomal organization of the U2 snRNA genes. However, U2 snDNA sites appear to be located on two chromosome pairs with medium size and similar morphologies in almost all Astyanax species. The U2 snDNA cluster stability could be the result of an evolutionary advantage or association with specific DNA segments or particular regions of the genome, which may have facilitated the maintenance of U2 snDNA on two chromosome pairs in South American Astyanax species.

\section{Acknowledgments}

The authors are grateful to Dr. Anderson Luis Alves (EMBRAPA) for provision of aquarium species and Dr. Carlos Alexandre Fernandes (UEMS) for provision of laboratory facilities for cytogenetic preparations. This study was supported by CAPES (Coordenadoria de Aperfeiçoamento de Pessoal de Nível Superior).

\section{Disclosure Statement}

No competing financial interests exist.

\section{References}

1. Eschmeyer WN, Fong JD. Catalog of fishes. 2015; online available at http://researcharchive.calacademy.org/research/ ichthyology/catalog/fishcatmain.asp

2. Morelli S, Bertollo LAC, Foresti F, Moreira-Filho O, Toledo-Filho SA. Cytogenetic considerations on the genus Astyanax (Pisces, Characidae). I. Karyotypic variability. Caryologia 1983;36:235-244.
3. Fernandes CA, Martins-Santos IC. Cytogenetic studies in two populations of the Astyanax altiparanae (Pisces, Characiformes). Hereditas 2004;141:328-332.

4. Kavalco KF, Pazza R, Almeida-Toledo LF. Astyanax bockmanni vari and castro, 2007: an ambiguous karyotype in the Astyanax genus. Genetica 2009;136:135-139.

5. Torres-Mariano AR, Morelli S. Chromosomal analysis of Astyanax fasciatus (Pisces, Characidae) from the Araguari river, Uberlândia, MG, Brazil. Braz J Biol 2006;66(1A): 161-165.

6. Maistro EL, Oliveira C, Foresti F. Sympatric occurrence of two cytotypes of Astyanax scabripinnis (Characiformes, Characidae). Genet Mol Biol 2000;23:365-369.

7. Ferreira-Neto M, Artoni RF, Vicari MR, et al. Cytogenetics three sympatric karyomorphs in the fish Astyanax fasciatus (Teleostei, Characidae) do not seem to hybridize in natural populations. Comp Cytogent 2012;6:29-40.

8. Fernandes CA, Martins-Santos IC. Mapping of the $18 \mathrm{~S}$ and 5S ribosomal RNA genes in Astyanax altiparanae Garutti \& Britski, 2000 (Teleostei, Characidae) from the upper Paraná river basin, Brazil. Genet Mol Biol 2006;29:464-468.

9. Peres WAM, Bertollo LAC, Moreira-Filho O. Physical mapping of the $18 \mathrm{~S}$ and $5 \mathrm{~S}$ ribosomal genes in nine Characidae species (Teleostei, Characiformes). Genet Mol Biol 2008;31:222-226.

10. Hashimoto DT, Ferguson-Smith MA, Rens W, Foresti F, Porto-Foresti F. Chromosome mapping of $\mathrm{H} 1$ histone and $5 \mathrm{~S}$ rRNA gene clusters in three species of Astyanax (Teleostei, Characiformes). Cytogenet Genome Res 2011;134:64-71.

11. Silva DMZA, Pansonato-Alves JC, Utsunomia R, et al. Chromosomal organization of repetitive DNA sequences in Astyanax bockmanni (Teleostei, Characiformes): dispersive location, association and co-localization in the genome. Genetica 2013;141:329-336.

12. Silva DMZdA, Pansonato-Alves JC, Utsunomia R, et al. Delimiting the origin of a B chromosome by FISH mapping, chromosome painting and DNA sequence analysis in Astyanax paranae (Teleostei, Characiformes). PLoS One 2014;9:e94896.

13. Silva DMZdA, Utsunomia R, Pansonato-Alves JC, Oliveira $\mathrm{C}$, Foresti F. Chromosomal mapping of repetitive DNA sequences in five species of Astyanax (Characiformes, Characidae) reveals independent location of $\mathrm{U} 1$ and $\mathrm{U} 2$ snRNA sites and association of U1 snRNA and 5S rDNA. Cytogenet Genome Res 2015;146:144-152.

14. Piscor D, Parise-Maltempi PP. Chromosomal mapping of $\mathrm{H} 3$ histone and 5S rRNA genes in eight species of Astyanax (Pisces, Characiformes) with different diploid numbers: syntenic conservation of repetitive genes. Genome 2016;59:167-172.

15. Foresti F, Almeida-Toledo LF, Toledo-Filho SA. Polymorphic nature of nucleous organizer regions in fishes. Cytogenet Cell Genet 1981;31:134-141.

16. Piscor D, Ribacinko-Piscor DB, Fernandes CA, PariseMaltempi PP. Cytogenetic analysis in three Bryconamericus species (Characiformes, Characidae): first description of the 5S rDNA-bearing chromosome pairs in the genus. Mol Cytogenet 2013;6:13.

17. Sambrook J, Russell DW. Molecular cloning: a laboratory manual. Cold Spring Harbor Laboratory Press, Cold Spring Harbor, Long Island, New York, 2001.

18. Pendás AM, Morán $\mathrm{P}$, Freije JP, García-Vázquez E. Chromosomal location and nucleotide sequence of two tandem repeats of the Atlantic salmon 5S rDNA. Cytogenet Cell Genet 1994;67:31-36. 
19. Martins C, Galetti Jr PM. Chromosomal localization of $5 \mathrm{~S}$ rDNA genes in Leporinus fish (Anostomidae, Characiformes). Chromosome Res 1999;7:363-367.

20. Bueno D, Palacios-Gimenez OM, Cabral-de-Mello DC. Chromosomal mapping of repetitive DNAs in Abracris flavolineata reveal possible ancestry for the B chromosome and surprisingly H3 histone spreading. PLoS One 2013;8: e66532.

21. Pinkel D, Straume T, Gray JW. Cytogenetic analysis using quantitative, high-sensitivity, fluorescence hybridization. Proc Natl Acad Sci U S A 1986;83:2934-2938.

22. Cabral-de-Mello DC, Moura RC, Martins C. Chromosomal mapping of repetitive DNAs in the beetle Dichotomius geminatus provides the first evidence for an association of 5S rRNA and histone $\mathrm{H} 3$ genes in insects, and repetitive DNA similarity between the B chromosome and A complement. Heredity 2010;104:393-400.

23. Moreira-Filho O, Bertollo LAC. Astyanax scabripinnis (Pisces, Characidae): a species complex. Rev Bras Genet 1991; 14:331-357.

24. Pazza R, Kavalco SAF, Bertollo LAC. Chromosome polymorfism in Astyanax fasciatus (Teleostei, Characidae) 1. Karyotype analysis, Ag-NORs and mapping of $18 \mathrm{~S}$ and $5 \mathrm{~S}$ ribosomal genes in sympatric karyotypes and their possible hybrid forms. Cytogenet Genome Res 2006;112: 313-319.

25. Paiz LM, Baumgärtner L, da Graça WJ, Margarido VP. Basic cytogenetics and physical mapping of ribosomal genes in four Astyanax species (Characiformes, Characidae) collected in Middle Paraná River, Iguassu National Park: considerations on taxonomy and systematics of the genus. Comp Cytogenet 2015;9:51-65.

26. Piscor D, Alves AL, Parise-Maltempi PP. Chromosomal microstructure diversity in three Astyanax (Characiformes, Characidae) species: comparative analysis of the chromosomal locations of the 18S and 5S rDNAs. Zebrafish 2015;12:81-90.
27. Vicari MR, Noleto RB, Artoni RF, Moreira-Filho O, Bertollo LAC. Comparative cytogenetics among species of the Astyanax scabripinnis complex. Evolutionary and biogeographical inferences. Genet Mol Biol 2008;31:173-179.

28. Supiwong W, Liehr T, Cioffi MB, et al. Karyotype and cytogenetic mapping of 9 classes of repetitive DNAs in the genome of the naked catfish Mystus bocourti (Siluriformes, Bagridae). Mol Cytogenet 2013;6:51.

29. Merlo MA, Pacchiarini T, Portela-Bens S, Cross I, Manchado M, Rebordinos L. Genetic characterization of Plectorhinchus mediterraneus yields important clues about genome organization and evolution of multigene families. BMC Genet 2012;13:33.

30. Utsunomia R, Scacchetti PC, Pansonato-Alves JC, Oliveira C, Foresti F. Comparative chromosome mapping of U2 snRNA and 5S rRNA genes in Gymnotus species (Gymnotiformes, Gymnotidae): evolutionary dynamics and sex chromosome linkage in G. pantanal. Cytogenet Genome Res 2014;142:286-292.

31. Dowling TE, Martasian DP, Jeffery WR. Evidence for multiple genetic forms with similar eyeless phenotypes in the blind cavefish, Astyanax mexicanus. Mol Biol Evol 2002;19:446-455.

Address correspondence to: Patricia Pasquali Parise-Maltempi, PhD Laboratório de Citogenética Departamento de Biologia Instituto de Biociências Universidade Estadual Paulista “Júlio de Mesquita Filho” (UNESP) Av. $24 A, 1515$ Rio Claro 13506-900 Brazil

E-mail: parise@rc.unesp.br 